\title{
Phorbol Esters Affect Multiple Steps in $\beta$-Amyloid Precursor Protein Trafficking and Amyloid $\beta$-Protein Production
}

\author{
Edward H. Koo \\ Department of Pathology and Center for Neurologic Diseases, \\ Brigham and Women's Hospital, and Department of Pathology, \\ Harvard Medical School, Boston, Massachusetts, U.S.A.
}

\begin{abstract}
Background: Amyloid $\beta$-protein $(\mathrm{A} \beta)$, the major constituent of amyloid deposits found in Alzheimer's disease, is derived from the $\beta$-amyloid precursor protein $(\beta \mathrm{PP})$. Constitutive proteolysis by $\alpha$-secretase and secretion of soluble $\beta \mathrm{PP}(\beta \mathrm{PP})$ are stimulated by protein kinase $C(\mathrm{PKC})$ activation, whereas $\mathrm{A} \beta$ production and release are inhibited. The cellular mechanism that underlies the PKC-mediated down-regulation of $A \beta$ generation is unclear. Because endocytic processing of $\beta P P$ from the cell surface is a major pathway of $A \beta$ production, the effect of PKC activation by phorbol 12,13-dibutyrate $(\mathrm{PDBu})$ on endocytic trafficking of $\beta \mathrm{PP}$ was examined.

Materials and Methods: In this study, trafficking of $\beta$ PP was assayed in Chinese hamster ovary cells ( $\mathrm{CHO}$ ) cells stably transfected with full-length $\beta$ PP751.
\end{abstract}

Results: Treatment with PDBu resulted in a rapid and striking reduction of up to $80 \%$ in the amount of $\beta \mathrm{PP}$ at the cell surface. This loss of cell-surface molecules could not be accounted for by changes in the trafficking of cell-surface $\beta$ PP molecules, as determined by a radiolabeled antibody assay. Rather, the decrease in $\beta$ PP was due primarily to a reduction in the sorting of $\beta P P$ to the cell surface. This alteration was correlated with accelerated intracellular $\alpha$-secretase-mediated $\beta$ PP cleavage and accelerated $\beta$ PP trafficking in the exocytic pathway.

Conclusions: The data suggest that the displacement of $\beta P P$ away from the cell surface after phorbol ester treatment reduces the substrate available for endocytic processing and, in turn, results in the inhibition of $A \beta$ production.

\section{INTRODUCTION}

Alzheimer's disease is characterized by the deposition of amyloid $\beta$-protein $(\mathrm{A} \beta)$ in parenchyma and blood vessel walls and the intracellular accumulation of neurofibrillary tangles. $A \beta$ is derived by proteolysis of the larger $\beta$-amyloid precursor protein $(\beta \mathrm{PP})$, a $100-140 \mathrm{kDa}$ integral membrane protein. Processing of $\beta \mathrm{PP}$ in the constitutive pathway results in the secretion of a large $\mathrm{N}$-terminal soluble product $\left(\beta \mathrm{PP}_{\mathrm{s}}\right)$ and a membrane-retained C-terminal fragment of approximately $10 \mathrm{kDa}(1)$. Release of the $\mathrm{N}$-terminal ectodomain of $\beta$ PP results from cleavage by

Address correspondence and reprint requests to: Edward $\mathrm{H}$. Koo, Department of Neurosciences 069l, University of California, San Diego, 9500 Gilman Drive, La Jolla, CA 92093 0691, U.S.A. Phone: 619-822-1024; Fax: 619-822-1021.
" $\alpha$-secretase," an as yet unidentified protease that cleaves $\beta$ PP within the $A \beta$ sequence (2). Thus, formation of a full-length, 40-43 residue $\mathrm{A} \beta$ peptide is precluded by $\alpha$-secretase proteolysis. Both intracellular and cell-surface $\beta P P$ molecules are substrates for $\alpha$-secretase; indeed, accumulating evidence suggests proteolysis of $\beta \mathrm{PP}$ occurs in both cellular compartments (3).

Generation and release of $A \beta$ from $\beta$ PP occurs constitutively after two proteolytic events, designated " $\beta$ - and $\gamma$-secretase" cleavages at the $A \beta \mathrm{N}$ - and $\mathrm{C}$-termini, respectively. In addition to $\beta \mathrm{PP}_{\mathrm{s}}, \mathrm{A} \beta$ and a $3-\mathrm{kDa}$ fragment (p3) are normally produced and released from a variety of cells both in vivo and in vitro (4). The precise cellular compartments in which $A \beta$ is generated are unclear, although processing in an acidic 


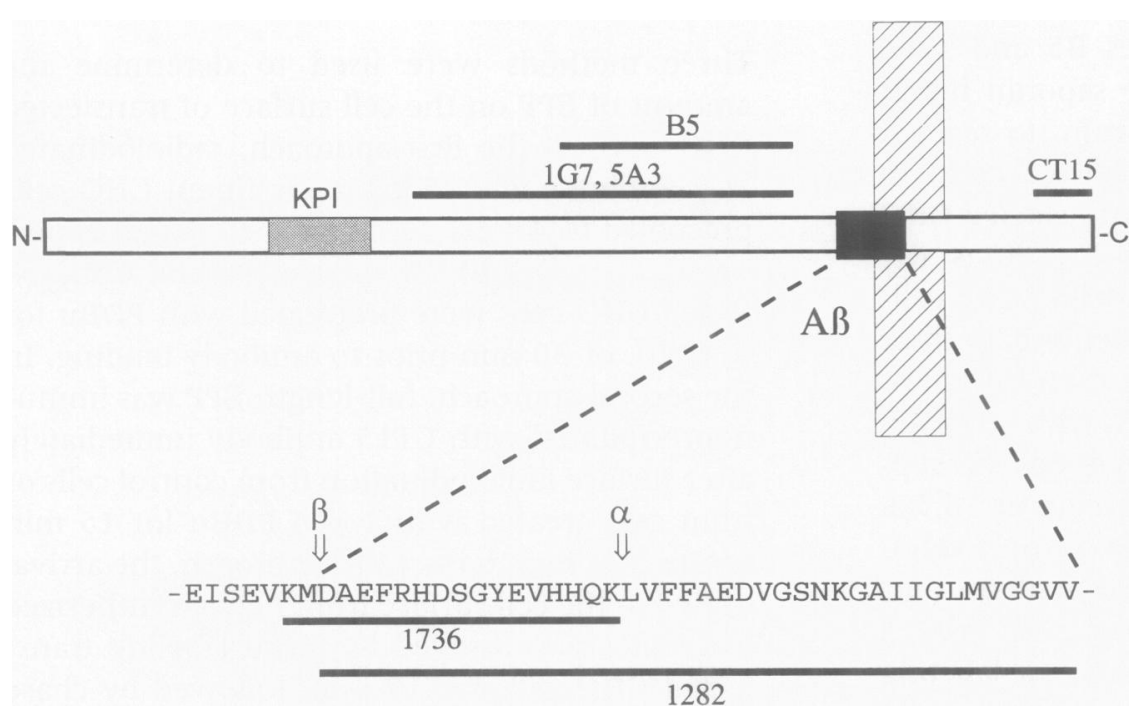

FIG. 1. Schematic of $\beta$ PP showing antibody epitopes

The black box represents $A \beta$ with the amino acid sequence shown below. The vertical dashed boxes and horizontal stippled box represent the plasma membrane and the Kunitz protease inhibitor (KPI) domain, respectively. " $\alpha$ " and " $\beta$ " indicate $\alpha$ - and $\beta$-secretase cleavage sites. Horizontal black bars represent the approximate epitopes of antibodies B5, 5A3, lG7, CT15, 1736, and 1282. compartment appears to be required. Both secretory (5) and endocytic (6) pathways have been shown to contribute to $A \beta$ production; however, the major source of $A \beta$ derived from wild-type $\beta$ PP in cultured cells appears to be the endocytic pathway $(6,7)$.

Activation of protein kinase C (PKC) by a variety of agents stimulates $\alpha$-secretase-mediated $\beta \mathrm{PP}_{\mathrm{s}}$ secretion (8). This alteration, however, does not require direct phosphorylation of $\beta P P$, which suggests an indirect mode of action of PKC on regulating $\beta$ PP cleavage $(9,10)$. Acceleration of $\beta P P$ metabolism through the $\alpha$-secretory pathway by PKC activation results in a corresponding decrease in $\beta$-secretory processing and $\mathrm{A} \beta$ production $(11,12)$. The cellular and molecular basis of the PKC-mediated reduction of $A \beta$ production remains to be clearly defined. In view of our results indicating a major role of the endocytic pathway in $A \beta$ production, this study was designed to determine how processing of $\beta$ PP in this pathway is affected by PKC activation. To date, cell-surface receptors have shown heterogeneous and unpredictable responses to phorbol esters with respect to trafficking in the receptor-mediated pathway (13). The results showed that PKC activation by phorbol esters leads to a rapid and major reduction in $\beta P P$ sorting to the cell surface. In turn, this loss in cell-surface $\beta$ PP results in a corresponding reduction in available substrate for endocytic processing and $A \beta$ production.

\section{MATERIALS AND METHODS}

\section{Cell Culture and Metabolic Labeling}

Chinese hamster ovary (CHO) cells were grown in Dulbecco's modified Eagle's medium containing $10 \%$ fetal calf serum. Stably transfected $\mathrm{CHO}$ cell line expressing wild-type $\beta$ PP751 has been established previously (6). In pulse-chase experiments, confluent $\beta$ PP-transfected $\mathrm{CHO}$ cells were labeled with ${ }^{35} \mathrm{~S}$-methionine for $10 \mathrm{~min}$ and chased for $20 \mathrm{~min}$ or $2 \mathrm{hr}$ with or without $1 \mu \mathrm{M}$ phorbol-12,13-dibutyrate (PDBu). This labeling paradigm examines only the effect of $\mathrm{PDBu}$ on post-translational events. Immunoprecipitations of $\mathrm{A} \beta$ (media) and full-length $\beta \mathrm{PP}$ (cell lysates) were carried out with 1282 , an antibody recognizing $A \beta$, and a $C$-terminal antibody, CT15, respectively $(14,15)$ (Fig. 1). $\beta \mathrm{PP}_{\mathrm{s}}$ from media and saponin buffer (see below) were immunoprecipitated by antibodies B5 (16) and 1736 (12), which recognize the extracellular domain of $\beta$ PP or $\alpha$-secretase cleaved $\beta \mathrm{PP}_{\mathrm{s}}$, respectively (Fig. 1).

To detect intracellularly cleaved $\beta \mathrm{PP}_{\mathrm{s}}$, $\mathrm{CHO}$ cells pulse-labeled for $10 \mathrm{~min}$ were quickly chilled with ice-cold Dulbecco's phosphate buffered saline (DPBS) after a 10- or 20-min chase period. The cells were then incubated at $4^{\circ} \mathrm{C}$ for 40 min with $0.1 \%$ saponin in DPBS supplemented with protease inhibitors as described (17). Saponin was used because this mild detergent permeabilizes cells without solubilizing cell membranes, thereby allowing soluble intracellu- 
lar molecules to diffuse out of the cells. Immunoprecipitations using antibodies B5 and 1736 were then carried out from the saponin buffer supplemented with $10 \%$ calf serum, to recover $\beta \mathrm{PP}_{\mathrm{s}}$ released from the permeabilized cells. In surface iodination experiments, transfected $\mathrm{CHO}$ cells were radioiodinated with $\mathrm{Na}^{125} \mathrm{I}$ as described previously (18). After labeling, the cells were chased with normal CHO medium, with or without PDBU, for $2 \mathrm{hr}$. A $\beta$ was then immunoprecipitated from the chase media with antibody 1282. The immunoprecipitated material was separated by SDS-PAGE ( $6 \%$ tris-glycine or $16.5 \%$ tris-tricine gels for $\beta \mathrm{PP}_{\mathrm{s}}$ or $\mathrm{A} \beta$, respectively). Dried gels were either quantitated by densitometry after fluorographic enhancement or exposed directly to phosphorimager screen. All labeling experiments were repeated two to four times.

\section{Kinetics of Surface $\beta P P$ Trafficking}

To determine the kinetics of $\beta$ PP secretion and internalization from the cell surface, a method that quantitatively assesses both the release of $\beta \mathrm{PP}_{\mathrm{s}}$ into media and the internalization of $\beta \mathrm{PP}$ from the cell surface using radiolabeled 1G7 monoclonal antibody was performed as described (19). 1G7 is a monoclonal antibody that recognizes the extracellular domain of $\beta \mathrm{PP}$ within the midregion and was added at a concentration of $\approx 7 \mathrm{nM}$ to confluent $\mathrm{CHO}$ cells in 12 -well tissue culture plates. In brief, after incubation at $4^{\circ} \mathrm{C}$, the cells were either lysed immediately (time 0 ) or placed in prewarmed $\left(37^{\circ} \mathrm{C}\right)$ medium with or without PDBu. After 5, 10, 30, and $60 \mathrm{~min}$, the media were collected and cells rapidly chilled with ice-cold DPBS at $\mathrm{pH} 2.8$. After an additional 5-min wash with acidic buffer to detach residual surface-bound antibody, the cells were lysed in $0.2 \mathrm{M} \mathrm{NaOH}$. Radioactivity was then determined from the resultant three fractions: medium, acid wash, and acid resistant lysate, which represent secreted, cell-surface, and intracellular $\beta$ PP pools, respectively. TCA precipitable counts were used from media and lysate samples. Specific binding from all the antibodybinding experiments was calculated by subtracting the radioactivity from untransfected $\mathrm{CHO}$ cells performed in parallel. The results were then expressed in the three fractions at each time point as a percentage of the total radioactivity obtained at time 0 . All experiments were performed in triplicate and the results are expressed as average $( \pm$ SEM) of three repetitions.

\section{Cell-Surface $\beta$ PPP}

Three methods were used to determine the amount of $\beta \mathrm{PP}$ on the cell surface of transfected $\mathrm{CHO}$ cells. In the first approach, radioiodinated 1G7 antibody was added to confluent $\mathrm{CHO}$ cells precooled to $4^{\circ} \mathrm{C}$ as described (19). In all experiments, parallel sets of transfected and untransfected CHO cells were pretreated with PDBu for $0,5,10$, or 30 min prior to antibody binding. In the second approach, full-length $\beta$ PP was immunoprecipitated with CT15 antibody immediately after surface radioiodination from control cells or from cells treated with $1 \mu \mathrm{M}$ PDBu for $15 \mathrm{~min}$ before labeling. In the third approach, the arrival of $\beta$ PP to the cell surface from newly synthesized molecules was assayed by pulse labeling transfected CHO cells for $10 \mathrm{~min}$, followed by chase periods of 10 and $20 \mathrm{~min}$ with or without PDBu. After rapid cooling in ice-cold DPBS, surface $\beta$ PP molecules were recoved by incubating the cells with 5A3/1G7 monoclonal antibodies for $\mathrm{l} \mathrm{hr}$ at $4^{\circ} \mathrm{C} .5 \mathrm{~A} 3 / 1 \mathrm{G} 7$, which recognize nonoverlapping epitopes in the extracellular domain of $\beta \mathrm{PP}(6)$, were used together to obtain higher signal. The cells were then lysed in the presence of 2 -fold excess cold unlabeled transfected CHO cells. Antibody-bound cell-surface $\beta$ PP was then precipitated by incubating the lysates with precleared anti-mouse agarose beads (1). Immunoprecipitated material was fractionated by SDS-PAGE and visualized by autoradiography or phosphorimaging.

\section{RESULTS \\ BPP Trafficking after PDBu Treatment}

To examine whether PKC activation by PDBu affects the release or internalization of $\beta$ PP from the cell surface, the trafficking of $\beta$ PP molecules was assayed by radioiodinated $1 G 7$ antibody binding. In $\mathrm{CHO}$ cells expressing wild-type $\beta \mathrm{PP}$, cell-surface $\beta$ PP molecules are normally rapidly secreted or internalized (19). Approximately $30 \%$ of cell surface molecules are eventually secreted into the medium (Fig. 2A). When PDBu is added at the beginning of the chase period, $\beta P P$ secretion approximately doubled at each time point of the assay (Fig. 2A). This increase in $\beta P P$ release correlated with a decrease in $\beta$ PP internalization of $\sim 30 \%$ (Fig. $2 \mathrm{~B}$ ). The characteristically short residence time of $\beta \mathrm{PP}$ on the cell surface was not altered by $\mathrm{PDBu}$ treatment (Fig. 2C). 

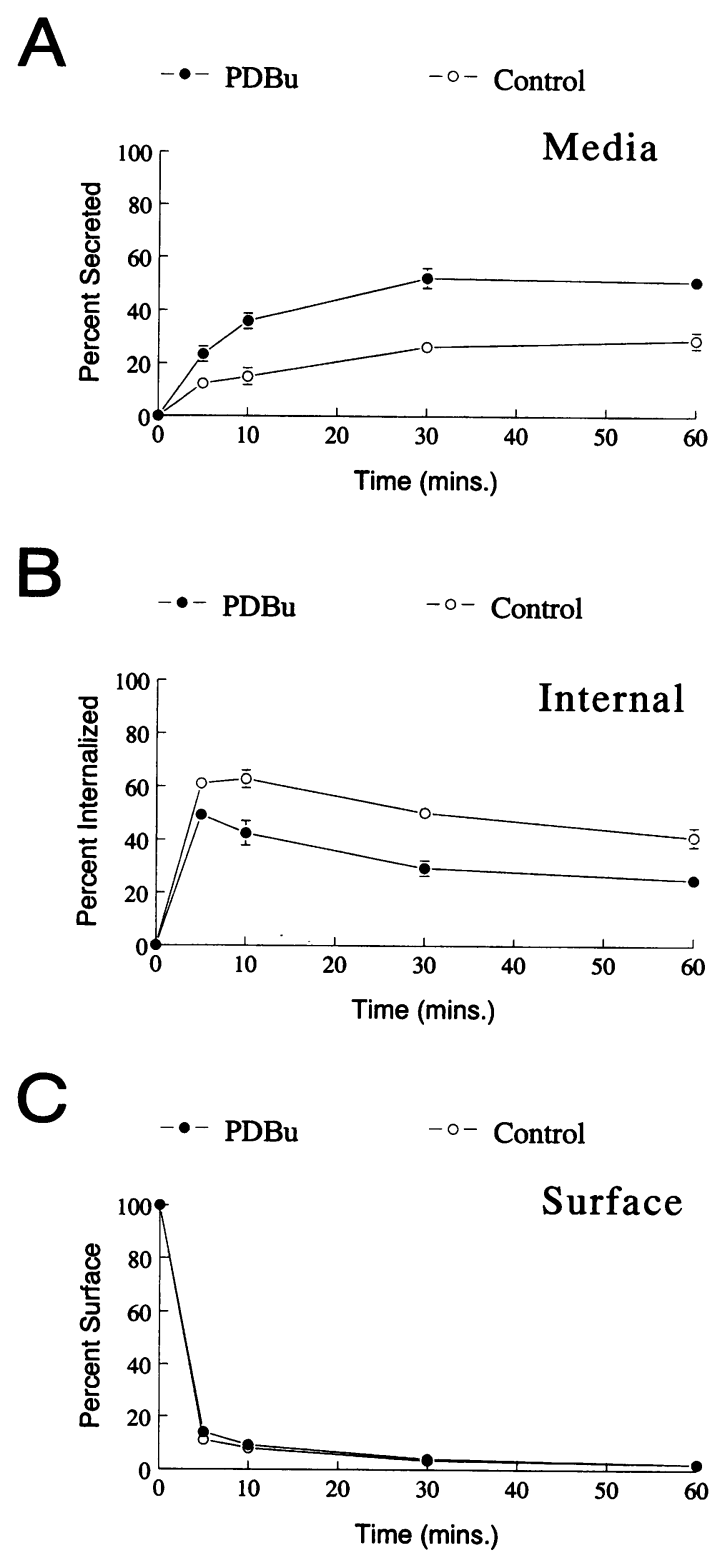

FIG. 2. Time-course study of cell-surface $\beta P P$ trafficking after PDBu

Radioiodinated 1G7 IgG was used to determine the rate of $\beta$ PP release and internalization from the cell surface in wild-type $\mathrm{CHO}$ cell line. The radioactivity from media (A), acid resistant lysates (B), and acid labile wash (C) was taken to represent secreted, internalized, and cell surface $\beta P P$, respectively. Within each of the three fractions, the result obtained at each time point is expressed as a percent of radioactivity of cell lysates obtained at time 0 . The value from the three fractions is $<100 \%$ because only TCA-precipitable radioactivity was taken into account and because of the variation in radioactivity obtained at each time point. The data are the averages \pm SEM of three independent experiments. The differences in the media and internalized fractions between control and PDBu treated cells were statistically significant at each of the four time points $(p<.05$ to $p<.003)$.
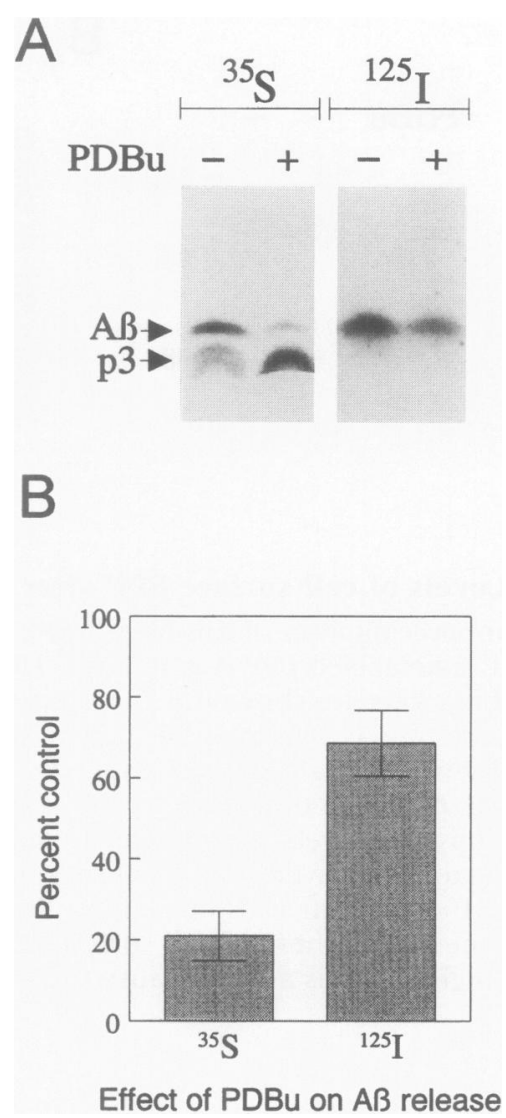

FIG. 3. Reduction in $A \beta$ production and release after PDBu

(A) Representative autoradiograms after the two different labeling methods. In both approaches, PDBu was added to wild-type $\mathrm{CHO}$ cells during the $2-\mathrm{hr}$ chase period after either a 10-min pulse labeling by ${ }^{35} \mathrm{~S}$-methionine or ${ }^{125} \mathrm{I}$ surface iodination. The decrease in $\mathrm{A} \boldsymbol{\beta}$ release in medium from ${ }^{35} \mathrm{~S}$-methionine-labeled cells is mirrored by an increase in $\mathrm{p} 3$ fragment. Recovery of $\mathrm{p} 3$ after surface iodination is inconsistent, as was shown previously (6). (B) The average percent reduction ( \pm SEM) of $A \beta$ release after ${ }^{35} \mathrm{~S}$-methionine $(n=4)$ and ${ }^{125}$ I surface labeling $(n=3)$. The difference between the two labeling methods was statistically significant $(p<.005)$.

\section{Release of $A \beta$ after PDBu Treatment}

Because $A \beta$ can be derived from cell-surface $\beta$ PP processed in the endocytic pathway, one would predict that the changes in $\beta$ PP internalization demonstrated above should result in a reduction in $A \beta$ release from surface precursors. Indeed, by using selective cell-surface iodination, addition of PDBu at the beginning of the chase period decreased recovery of labeled $A \beta$ from medium by $\sim 30 \%$ (Fig. 3). The magnitude of this decrease is consistent with the reduction of $\beta P P$ 

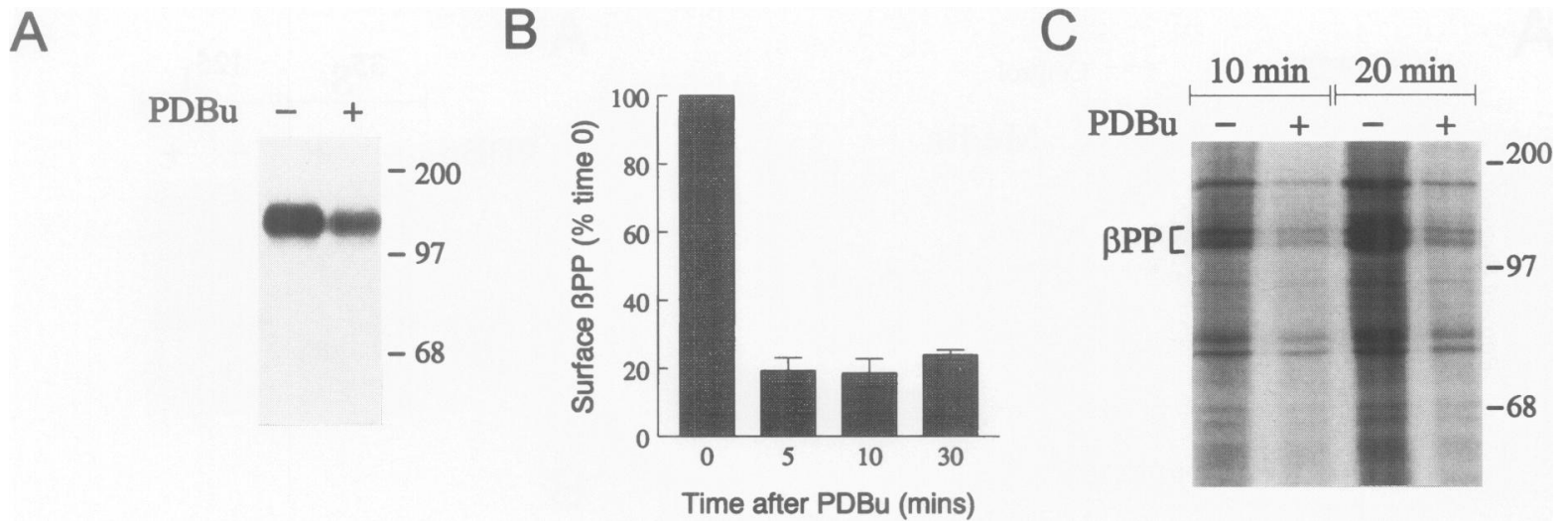

FIG. 4. Levels of cell-surface $\beta P P$ after PDBu

(A) Immunoprecipitation of full-length $\beta$ PP with CT15 antibody immediately after surface radioiodination. The amount of radiolabeled $\beta$ PP was reduced $15 \mathrm{~min}$ after PDBu pretreatment. Molecular weights determined from prestained markers are shown on the right. (B) Levels of cell-surface $\beta$ PP were measured by radioiodinated $1 \mathrm{G} 7$ monoclonal antibody binding. $\beta$ PP-transfected $\mathrm{CHO}$ cells were pretreated with PDBu for 5,10 , or 30 min before incubating with radiolabeled 1 G7 antibody. The results are expressed as percent radioactivity of untreated control cells measured at time 0 (average \pm SEM). (C) Levels of newly synthesized $\beta P P$ arriving to the cell surface were determined by selectively immunoprecipitating cell-surface $\beta$ PP with 5A3/1G7 monoclonal antibodies added to intact cells. Transfected wild-type $\mathrm{CHO}$ cells were pulse labeled with ${ }^{35} \mathrm{~S}$-methionine for $10 \mathrm{~min}$, followed by chase periods of 10 or 20 min with or without PDBu. Treatment with PDBu (+) showed marked reductions in the amount of newly synthesized cell surface $\beta$ PP (bracket) as compared with untreated control cells (-). The background is higher in this assay because the labeled lysates cannot be thoroughly precleared.

internalization after PKC activation (Fig. 2b). However, by metabolic labeling with ${ }^{35} \mathrm{~S}$-methionine, $\mathrm{A} \beta$ release was inhibited by $\sim 80 \%$ (Fig. 3), a result comparable to that reported by others (3). Therefore, when the production of $A \beta$ is measured from total cellular $\beta$ PP labeled by ${ }^{35} \mathrm{~S}$-methionine, $\mathrm{PDBu}$ inhibition of $\mathrm{A} \beta$ release is substantially greater than when only the cellsurface $\beta$ PP pool is examined by selective surface radioiodination.

\section{Cell Surface $\beta$ PP after PDBu Treatment}

The above results suggest that the effect of PDBu on trafficking of cell-surface $\beta$ PP molecules alone is insufficient to account for the overall decrease in $\mathrm{A} \beta$ production. Therefore, the amount of $\beta \mathrm{PP}$ on the cell surface after PDBu treatment was examined. As detected by surface radioiodination and immunoprecipitation, the level of cellsurface $\beta P P$ was markedly decreased 15 min after the addition of PDBu (Fig. 4A). To more accurately determine the time-dependent changes in surface $\beta$ PP expression, transfected $\mathrm{CHO}$ cells were pretreated with PDBu from 5 to $30 \mathrm{~min}$ and then assayed using radioiodinated monoclonal antibody 1 G7 binding. Surprisingly, an $80 \%$ decline in cell-surface $\beta$ PP was seen within 5 min of adding PDBu and remained at approximately the same level up to $30 \mathrm{~min}$ following treatment (Fig. 4B). Since changes in endocytic trafficking are minor (Fig. 2), in the range of $30 \%$, this reduction in cell-surface $\beta$ PP must be due to other factors, in particular, to diminished sorting of molecules to the cell surface.

Further evidence for this mechanism was provided by assaying for the arrival of $\beta$ PP to the cell surface from newly synthesized molecules. Using this approach, the levels of cell-surface $\beta$ PP derived from newly synthesized molecules were dramatically decreased after PDBu treatment (Fig. 4C). Specifically, treatment with PDBu for 10 to $20 \mathrm{~min}$ after the initial pulse labeling period resulted in $\sim 80-90 \%$ reduction in the amount of labeled cell-surface $\beta P P$. This experimental paradigm was such that the labeled molecules must have been newly synthesized and recently transported to the cell surface, in contrast to earlier experiments (Fig. 2, 4A and B) that examined the fate of the steady-state pool of $\beta P P$ already present at the cell surface when PDBu treatment was instituted. Thus, the latter pool is the summation of the decrease in nascent $\beta P P$ arriving to the cell surface, as well as to the increase in $\beta \mathrm{PP}_{\mathrm{s}}$ being released from the cell surface. 


\section{Intracellular Cleavage of $\boldsymbol{\beta P P}$}

To confirm the above postulate that targeting of $\beta P P$ to the cell surface in the secretory/exocytic pathway is altered, intracellular $\beta \mathrm{PP}_{\mathrm{s}}$ was immunoprecipitated from saponin-treated $\mathrm{CHO}$ cells after treatment with PDBu using a pulse-chase paradigm. Treatment with low concentrations of saponin $(0.1 \%)$ permeabilized but did not solubilize cell membranes because in control experiments, full-length $\beta P P$ was virtually undetectable from the saponin buffer (Fig. 5A). Therefore, predominantly soluble nonmembrane-bound $\beta \mathrm{PP}$ molecules, i.e., $\beta \mathrm{PP}_{\mathrm{s}}$, were analyzed in this assay. As expected, secretion of $\beta \mathrm{PP}_{\mathrm{s}}$ into the medium was markedly increased by PDBu (Fig. 5B). The levels of $\beta \mathrm{PP}_{\mathrm{s}}$ immunoprecipitated by both $\mathrm{B} 5$ and 1736 antibodies were increased by 2 - to 3 -fold, which is consistent with the generation of increased amounts of $\alpha$-secretase cleaved species. Concomitantly, as determined by saponin permeabilization, the amount of intracellular $\beta \mathrm{PP}_{\mathrm{s}}$ detected by both $\mathrm{B} 5$ and 1736 immunoprecipitations was markedly decreased, by $\sim 70 \%$. This finding suggests that there was a redistribution of the intracellular pool of $\beta \mathrm{PP}_{\mathrm{s}}$ molecules into the medium, in other words, an acceleration of both $\alpha$-secretory cleavage and release of $\beta \mathrm{PP}_{s^{\prime}}$ bypassing the cell surface.

\section{DISCUSSION}

The data presented above provide compelling evidence that PKC activation by phorbol esters results in major and rapid alterations in $\beta$ PP trafficking in the endocytic pathway. In particular, an $80-90 \%$ decrease in the targeting of $\beta$ PP molecules to the cell surface was seen within minutes of PDBu treatment. Surprisingly, the reduction in the amount of cell-surface $\beta$ PP after PDBu treatment was caused by a major decrement in sorting of $\beta$ PP to the cell surface and only secondarily from an increase in secretion of cellsurface molecules. This loss of cell-surface $\beta$ PP molecules derived from the exocytic pathway would lead to a corresponding decrease in substrate available for subsequent endocytic processing. Thus, the effect of phorbol esters on trafficking of $\beta \mathrm{PP}$ molecules at the cell surface appears to be relatively minor. Finally, the data showed that the perturbations of $\beta$ PP sorting to the cell surface are caused principally by an increase in intracellular $\alpha$-secretase cleavage and

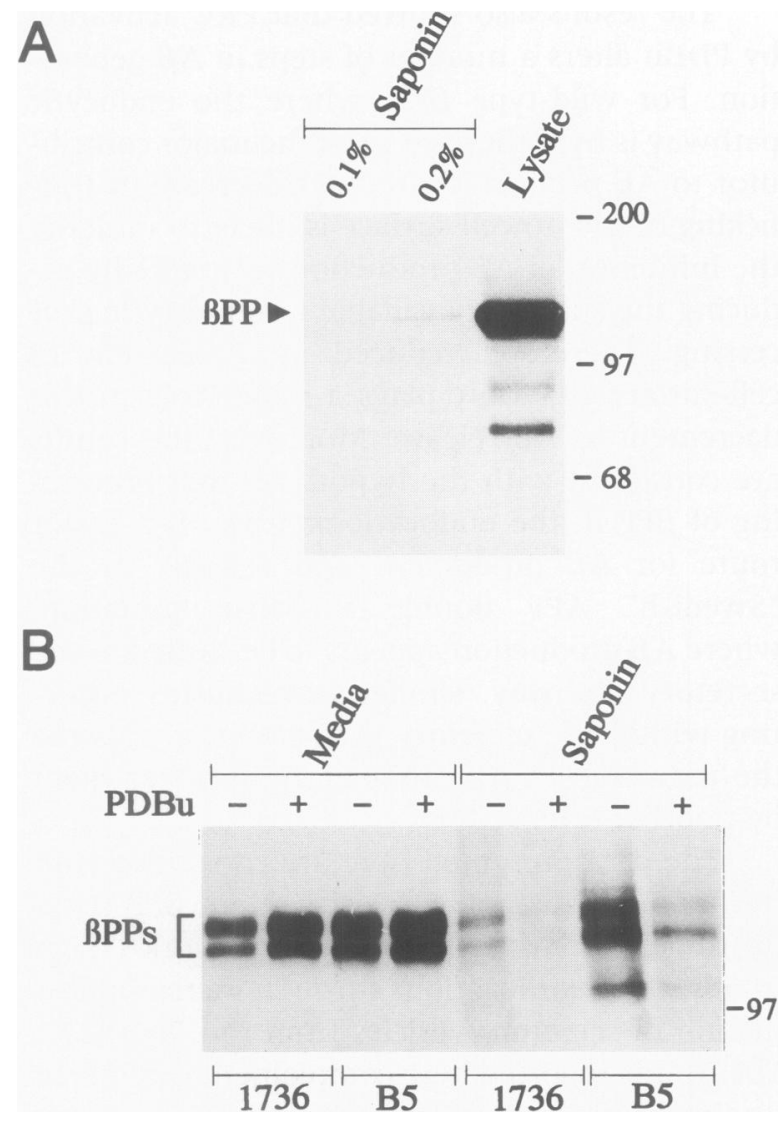

FIG. 5. Immunoprecipitation of $\beta P P_{s}$ after saponin treatment

(A) Transfected wild-type CHO cells were pulse labeled with ${ }^{35} \mathrm{~S}$-methionine for 10 min without a chase period and treated either with $0.1 \%$ or $0.2 \%$ saponin at $4^{\circ} \mathrm{C}$ for $40 \mathrm{~min}$. Immunoprecipitation of full-length $\beta$ PP was carried out with CT15 antibody from saponin buffer (saponin) or cell lysate (lysate), the latter after solubilization with $1 \%$ NP40. Fulllength $\beta$ PP (arrowhead) was readily precipitated from cell lysate but was minimally detectable from the buffer fraction treated with $0.2 \%$ saponin and essentially undetectable in the $0.1 \%$ saponin buffer. (B) Immunoprecipitations of intracellular and secreted $\beta P_{s}$ after PDBu treatment. Transfected $\mathrm{CHO}$ cells were labeled by ${ }^{35} \mathrm{~S}$-methionine for $10 \mathrm{~min}$ and chased for 20 min with (+) or without (-) PDBu. $\beta \mathrm{PP}_{s}$ was immunoprecipitated from medium (media) and from saponin buffer (saponin) with antibodies B5 and 1736. Levels of immunoprecipitable $\beta \mathrm{PP}_{\mathrm{s}}$ were higher in media with both 1736 and B5 antibodies but lower intracellularly when recovered from the saponin buffer, after PDBu treatment. Antibody 1736 consistently precipitates less $\beta \mathrm{PP}_{\mathrm{s}}$ than antibody $\mathrm{B} 5$, accounting for the lower signal in the 1736 lanes. In low-percentage gels, $\beta \mathrm{PP}_{\mathrm{s}}$ from CHO cells migrates as a doublet.

an increase in the trafficking of $\beta \mathrm{PP}_{\mathrm{s}}$ out of the cell, and to a much lesser degree, from increased $\alpha$-secretase activity at the cell surface. 
The results also showed that PKC activation by PDBu alters a number of steps in $A \beta$ generation. For wild-type $\beta P P$, where the endocytic pathway is hypothesized to be the major contributor to $A \beta$ production, the net decrease in trafficking of $\beta$ PP to cell surface is likely to underlie the inhibition of $A \beta$ production by markedly reducing the substrate available for endocytic processing. Therefore, reduced internalization of cell-surface $\beta$ PP only plays a minor role in this decrement in $A \beta$ release. Moreover, the results are consistent with the hypothesis that processing of $\beta P P$ in the endocytic pathway is a major route for $A \beta$ production and release. In the "Swedish" APP double missense mutation, where $A \beta$ production appears to be shifted to the secretory pathway, similar mechanisms occurring within the secretory pathway may underlie the reduction in $A \beta$ production after treatment by phorbol esters $(20)$.

The data presented here are consistent with the report that upon PKC activation, $\beta$ PP is redistributed from the trans Golgi network (TGN) to other cellular locations through increased formation of secretory vesicles from the TGN (21). The results reported here complement this recent finding in demonstrating a large displacement of $\beta$ PP away from the cell surface and an increase in the trafficking of $\beta$ PP out of the cell. However, the data also demonstrated that the acceleration in $\alpha$-secretase cleavage that accompanies this perturbation in $\beta$ PP sorting is only minimally increased at the plasma membrane. Therefore, $\alpha$-secretase activity enhanced by PKC activation must occur in an intracellular compartment that remains to be defined (22). Two potential mechanisms mediating this PKC effect come to mind: a direct PKC-mediated activation of intracellular $\alpha$-secretase activity, or a displacement of $\beta$ PP to the compartment where $\alpha$-secretase is located.

Finally, in addition to phorbol esters, a number of other agents have been shown to both increase $\beta \mathrm{PP}_{\mathrm{s}}$ secretion and decrease $\mathrm{A} \beta$ production (8). These include treatment by cytokines, muscarinic activation, and inhibition of protein phosphatases. In view of the multiple effects of PKC activation by PDBu on $\beta$ PP trafficking and processing, one would hypothesize that the other agents will show a range of cellular alterations affecting $\beta P P$ and $A \beta$ production and release. Understanding the multitude of cellular perturbations that alter $\beta$ PP trafficking should generate additional potential targets for inhibiting $A \beta$ generation.

\section{ACKNOWLEDGMENTS}

I thank Sharon Squazzo and Leslie Caromile for invaluable technical assistance, Drs. Christian Haass, Albert Hung, Sam Sisodia, and David Teplow for helpful discussions, and Drs. Dale Schenk and Dennis Selkoe for use of various antisera. This work was supported by grants from the Alzheimer's Association (ZEN 94-011) and the National Institutes of Health (AG12376 and NS01812).

\section{REFERENCES}

1. Weidemann A, Konig G, Bunke D, et al. (1989) Identification, biogenesis, and localization of precursor of Alzheimer's disease A4 amyloid protein. Cell 57: 115-126.

2. Esch FS, Keim PS, Beattie EC, et al. (1990) Cleavage of amyloid beta peptide during constitutive processing of its precursor. Science 248: 1122-1124.

3. Checler F. (1995) Processing of the $\beta$-amyloid precursor protein and its regulation in Alzheimer's disease. J. Neurochem. 65: 14311444.

4. Haass C, Selkoe DJ. (1993) Cellular processing of $\beta$-amyloid precursor protein and the genesis of amyloid $\beta$-peptide. Cell 75: 10391042.

5. Busciglio J, Gabuzda DH, Matsudaira P, Yankner BA. (1993) Generation of $\beta$-amyloid in the secretory pathway in neuronal and nonneuronal cells. Proc. Natl. Acad. Sci. U.S.A. 90: 2092-2096.

6. Koo EH, Squazzo SL. (1994) Evidence that production and release of amyloid $\beta$-protein involves the endocytic pathway. J. Biol. Chem. 269: 17386-17389.

7. LeBlanc AC, Gambetti P. (1994) Production of Alzheimer $4 \mathrm{kDa} \beta$-amyloid peptide requires the C-terminal cytosolic domain of the amyloid precurso protein. Biochem. Biophys. Res. Commun. 204: 1371-1380.

8. Gandy S, Greengard P. (1994) Processing of Alzheimer $A \beta$-amyloid precursor protein: Cell biology, regulation, and role in Alzheimer disease. Int. Rev. Neurobiol. 36: 29-50.

9. da Cruz e Silva OAB, Iverfeldt K, Oltersdorf $\mathrm{T}$, et al. (1993) Regulated cleavage of Alzheimer $\beta$-amyloid precursor protein in the absence of the cytoplasmic tail. Neuroscience. 57: 873-877.

10. Hung AY, Selkoe DJ. (1994) Selective 
ectodomain phosphorylation and regulated cleavage of $\beta$-amyloid precursor protein. EMBO J. 13: 534-542.

11. Buxbaum JD, Koo EH, Greengard P. (1993) Protein phosphorylation inhibits production of Alzheimer amyloid $\beta / \mathrm{A} 4$ peptide. Proc. Natl. Acad. Sci. U.S.A. 90: 9195-9198.

12. Hung AY, Haass C, Nitsch RM, et al. (1993) Activation of protein kinase $C$ inhibits cellular production of the amyloid $\beta$-protein. J. Biol. Chem. 268: 22959-22962.

13. Backer JM, King GL. (1991) Regulation of receptor-mediated endocytosis by phorbol esters. Biochem. Pharmacol. 41: 1267-1277.

14. Podlisny MB, Ostaszewski BL, Squazzo SL, et al. (1995) Aggregation of secreted amyloid $\beta$-protein into sodium dodecyl sulfate-stable oligomers in cell culture. J. Biol. Chem. 270: 9564-9570.

15. Sisodia SS, Koo EH, Hoffman PN, Perry G, Price DL. (1993) Identification and transport of full-length amyloid precursor proteins in rat peripheral nervous system. J. Neurosci. 13: $3136-3142$.

16. Oltersdorf T, Ward PJ, Henriksson T, et al. (1990) The Alzheimer amyloid precursor protein: Identification of a stable intermediate in the biosynthetic/degradative pathway. J. Biol. Chem. 265: 4492-4497.
17. Simmons CF Jr, Schwartz AL. (1984) Cellular pathways of galactose-terminal ligand movement in a cloned human hepatoma cell line. Mol. Pharmacol. 26: 509-519.

18. Perez RG, Squazzo SL, Koo EH. (1996) Enhanced release of the amyloid $\beta$-protein from codon 670/671 "Swedish" mutant $\beta$-amyloid precursor protein occurs in both secretory and endocytic pathways. J. Biol. Chem. 271: 9100-9107.

19. Koo EH, Squazzo SL, Selkoe DJ, Koo CH. (1996) Trafficking of cell surface amyloid $\beta$-protein precursor. I. Secretion, endocytsosis, and recycling detected by labeled monoclonal antibody. J. Cell Sci. 109: 991-998.

20. Felsenstein KM, Ingalls KM, Hunihan LW, Roberts SB. (1994) Reversal of the Swedish familial Alzheimer's disease mutant phenotype in cultured cells treated with phorbol 12,13-dibutyrate. Neurosci. Lett. 174: 173-176.

21. Xu H, Greengard P, Gandy S. (1995) Regulated formation of golgi secretory vesicles containing Alzheimer $\beta$-amyloid precursor protein. J. Biol. Chem. 270: 23243-23245.

22. Arribas J, Massague J. (1995) Transforming growth factor- $\alpha$ and $\beta$-amyloid precursor protein share a secretory mechanism. J. Cell Biol. 128: 433-441.

Communicated by P. Greengard. Accepted November 5, 1996. 